Viktorija Soṇeca, $L L M$

Latvijas Universitātes Juridiskās fakultātes doktorante

\title{
JĒDZIENA “NACIONĀLĀ IDENTITĀTE” TVĒRUMS PĀRĀKUMA PRINCIPA KONTEKSTĀ
}

\section{SCOPE OF 'NATIONAL IDENTITY' CONCEPT IN CONTEXT OF PRINCIPLE OF PRIMACY}

\begin{abstract}
Summary
According to Article 4(2) of TEU, EU must respect the equality of Member States before the Treaties, as well as their national identities, inherent in their fundamental structures, political and constitutional, inclusive of regional and local self-government. Such duty of EU had already been included in the Maastricht Treaty, and, although it seems to be crystal clear that the principle of primacy of EU law can be limited in case of Member State's 'national identity', almost all the constitutional courts of Member States have declared their own limits to this principle. Therefore, the author in this paper will discuss the coverage of the principle of primacy of EU law versus Member States' national identity. This task is achieved both by analysing the development of the principle of primacy of EU law by CJEU' case law, and also by focusing on its importance in the Member States and its limits in the context of concepts like 'national identity' and 'constitutional identity', as the concept 'constitutional identity' has been used to identify the scope of what is protected by Article 4(2) of TEU, even though Article 4(2) of TEU refers only to Member States' national identity, inherent in their fundamental structures.
\end{abstract}

Atslēgvārdi: nacionālā identitāte, pārākuma princips, konstitucionālā identitāte

Keywords: principle of primacy, national identity, constitutional identity

\section{Ievads}

Lìguma par Eiropas Savienību (turpmāk - LES) 4. panta otrā daļa ir viens no Eiropas Savienības (turpmāk - ES) pārākuma principa ierobežojošiem instrumentiem, kurš izriet no ES pamatlīguma. Tomēr ne ES, t. i., viena no tās iestādēm, ne arī Eiropas Savienības Tiesa (turpmāk - EST) nav sniegusi nepārprotamu un izsmeḷošu skaidrojumu par LES 4. panta otrajā dạ̦ā ietverto jēdzienu "nacionālā identitāte" un tā tvērumu. Tāpat jāatzīmē, ka pastāv neizpratne, vai jēdziens "nacionālā identitāte" ir/nav sinonīms jēdzienam "konstitucionālā identitāte".

Savukārt par pārākuma principu norādāms, ka, kḹūstot par ES dalībvalsti, atbilstoši LES $^{1}$ un Lìgumam par Eiropas Savienības darbïbu (turpmāk - LESD) ${ }^{2}$ valsts nodod ES daļu savas kompetences, vienlaikus saglabājot suverenitāti. ${ }^{3}$ Minētais izriet ne tikai

Liguma par Eiropas Savienību 5. pants, OV C 115, 9.5.2008, 18. lpp.

Liguma par Eiropas Savienības darbibu 6. pants, OV C 326, 26.10.2012., 52.-53. lpp.

3 Levits E. Satversme un Eiropas Savienība. Jurista Vārds, 8.06.2000., Nr. 23. 
no LES 50. panta, kur paredzētas dalībvalsts tiesības izstāties no ES, bet arī uzsvērts EST spriedumā Wightman u. c. ${ }^{4}$ lietā. ${ }^{5}$ Norādāms, ka līdzīgus apsvērumus Satversmes tiesa izteica jau Lisabonas ${ }^{6}$ spriedumā.

Tādējādi rakstā tiks apskatīti jēdzieni "nacionālā identitāte" un "konstitucionālā identitāte” LES 4. panta otrās dal̦as kontekstā, kā arī pārākuma princips, kuru ierobežo minētā tiesību norma, jo norādìtais princips nav absolūts un gandrīz katra dalībvalsts noteikusi tā piemērošanas robežas ${ }^{7}$, izn,emot, piemēram, Rumāniju ${ }^{8}$. Lìdz ar to pārākuma princips nedrīkst tikt apskatīts vienpusēji, t. i., atrauti no tā piemērošanas ierobežojumiem, kas izriet, piemēram, no dalībvalstu izpratnes par normatīvo aktu hierarhiju, kā arī LES 4. panta otrās dal̦as. ${ }^{9}$ Respektīvi, pārākuma principa ierobežojošais faktors vienā gadījumā ir dalībvalsts nostāja, savukārt otrā gadījumā ierobežojums, kas izriet no ES pamatlīguma.

\section{Pārākuma principa attīstība}

\subsection{Dalībvalstu kopīgās vērtības}

ES tiesības raksturo vairākas iezīmes, t. i., šīs tiesības radušās no autonoma avota, kas izveidots ar ES pamatlīgumiem ${ }^{10}$, minēto tiesību pārākums pār dalībvalstu tiesībām, ${ }^{11}$ kā arī šo tiesību tiešā iedarbība. Norādītās iezīmes izveidojušas principu, noteikumu un savstarpēji atkarīgu tiesisko attiecību strukturētu tīklu, kas saista ne tikai

4 EST 2018. gada 10. decembra spriedums lietā C-621/18 Wightman u.c.

5 Soņeca V. Brexit stāsts: to be continued vai tomēr the end. Jurista Vārds, 08.01.2019., Nr. 1 (1059), 21.-25. lpp.

6 Satversmes tiesas 2009. gada 7. aprīla spriedums lietā Nr. 2008-35-01, "Par likuma "Par Lisabonas līgumu, ar ko groza Līgumu par Eiropas Savienību un Eiropas Kopienas dibināšanas līgumu” atbilstību Latvijas Republikas Satversmes 101. pantam”.

7 Sk., piemēram: Claes M. The Validity and Primacy of EU Law and the "Cooperative Relationship" between National Constitutional Courts and the Court of Justice of the European Union. In: Maastricht Journal of European and Comparative Law, 2016, pp.151-170; Geiger R. EU Constitutionalism and the German Basic Law. The Jean Monnet / Robert Schuman Paper Series, 2005. Pieejams: http://aei.pitt.edu/8135/1/geigerfinal.pdf [aplūkots 11.05.2019.]; Stein T. Always Steering a Straight Course? The German Federal Constitutional Court and European Integration. ERA Forum, 2011. Pieejams: https://link.springer.com/content/pdf/10.1007/s12027-011-0200-5.pdf [aplūkots 11.05.2019.]: Carulla Santiago R. EU Law before the Spanish Constitutional Court. Review by the constitutional courts of proceedings before ordinary courts applying Community law. Strasbourg CCS 2006/05. Pieejams: http://www.venice.coe.int/webforms/documents/default.aspx?pdffile=CDLJU(2006)025-e [aplūkots 11.05.2019.].

8 Vataman D. The relationship between European Union law and Romanian law in the context of the law. Challenges of the Knowledge Society, pp. 545-551. Pieejams: http://cks.univnt.ro/uploads/ cks_2015_articles/index.php?dir=03_public_law\%2F\&download=CKS+2015_public_law_art.079. pdf [aplū $\bar{k}$ ots 11.05.2019.].

9 Ligums par Eiropas Savienību, OV C 115, 9.5.2008, 18. lpp.

10 Dibināšanas līgumi: Līgums par Eiropas Savienību (1992), Eiropas Ekonomikas kopienas dibināšanas līgums (1957), Eiropas Atomenerǵijas kopienas dibināšanas līgums (1957), Eiropas Ogḷu un tērauda kopienas dibināšanas līgums (1951).

11 EST 2013. gada 26. februāra spriedums lietā C-399/11 Melloni, 59. punkts. 
ES un tās dalībvalstis, bet arī dalībvalstis savā starpā, kuras apņēmušās, kā atgādināts LES 1. panta otrajā dalıāī ${ }^{12}$, veidot vēl ciešāku Eiropas tautu savienību. ${ }^{13}$

Kā izriet no LES preambulas, ES, tiekdamās nostiprināt savu tautu solidaritāti, respektē to vēsturi, kultūru un tradīcijas. ${ }^{14}$ Arī no LESD 167. panta izriet, ka ES respektē dalībvalstu nacionālās un reǵionālās atškiriỉbas. ${ }^{15}$ Lìdzīgs formulējums ietverts arī ES Pamattiesību hartas (turpmāk - Harta) preambulā, t. i., ES respektē Eiropas tautu kultūru un tradīciju dažādību, kā arī dalībvalstu nacionālo identitāti. ${ }^{16}$ Būtiski, ka gan LES, gan Hartā ietverts jēdziens "tauta" ${ }^{17}$ Šāds formulējums norāda uz ES mērḳi, kas pausts LES 1. pantā, t. i., veidojot ciešāku savstarpēju savienību, Eiropas tautām baudīt kopīgi mierīgu nākotni, kas būtu balstīta uz kopīgām vērtībām. ${ }^{18}$

Par kopīgām vērtībām runājot, jāuzsver, ka ES ir balstīta uz noteiktām vērtībām, kuras cieši saistītas ar tās mērḳiem. ${ }^{19}$ ES vērtības izriet no LES 2. panta, t. i., cilvēka cieņa, brīvība, demokrātija, vienlīdzība, tiesiskums un cilvēktiesības, tostarp minoritāšu tiesības. Šìs vērtības dalībvalstīm ir kopīgas sabiedrībā, kur valda plurālisms, tolerance, taisnīgums, solidaritāte un kur nav diskriminācijas, kā arī valda sieviešu un vīriešu līdztiesība. ${ }^{20} \mathrm{Lìdz}$ ar to LES 2. panta pirmajā teikumā noteiktās vērtības ir pamats uz tām balstītām institucionālām struktūrām un politikai gan ES, gan dalībvalstīs, ņemot vērā LES 2. panta otrajā teikumā minēto. ${ }^{21}$ Tomēr, lai arī dalībvalstīm un ES ir daudzas kopīgas vērtības, pastāv arī atškirīibas to izpratnē. Lìdz ar to, kamēr EST un dalībvalstu izpratne par vērtībām neatškiras, nepastāv arī domstarpības, tomēr brīdī, kad šī izpratne atškuiras, veidojas kolīzija, ņemot vērā, ka dalībvalstis nav gatavas upurēt no to konstitūcijām izrietošo izpratni par konkrētām vērtībām. ${ }^{22}$

\subsection{Pārākuma princips}

Attiecībā uz ES tiesību pārākumu norādāms, ka minētais ES pamatprincips nav iekḷauts ES pamatlīgumos, ${ }^{23}$ bet 1964. gadā iedibināts ar EST spriedumu Costa/E.N.E.L. ${ }^{24}$ lietā. Lai gan bija mēgénājums šo principu nostiprināt Līgumā par

12 Lìgums par Eiropas Savienïbu, OV C 115, 9.5.2008, 16. lpp.

13 EST 2014. gada 18. decembra atzinums Avis 2/13 Adhésion de l'Union à la CEDH, 167. punkts.

14 Līgums par Eiropas Savienïbu, OV C 115, 9.5.2008, 15. lpp.

15 Līguma par Eiropas Savienības darbïbu konsolidētā versija, OV C 326, 26.10.2012, 121.-122. lpp.

16 Eiropas Savienibas Pamattiesïbu harta, OJ V 326, 26.10.2012., 391. lpp.

17 Hartas preambula, LES preambula un LES 167. pants.

18 Satversmes tiesas 2009. gada 7. aprīla spriedums lietā Nr. 2008-35-01 "Par likuma "Par Lisabonas līgumu, ar ko groza Ligumu par Eiropas Savienību un Eiropas Kopienas dibināšanas līgumu" atbilstïbu Latvijas Republikas Satversmes 101. pantam",16.3. punkts.

19 Levits E. Eiropas Savienība kā vērtību savienība. Jurista Vārds, 08.05.2018., Nr. 19 (1025), 39.-49. lpp.

20 Ligums par Eiropas Savienïbu, OV C 115, 9.5.2008, 17. lpp.

21 Levits E., 2018, 39.-49. lpp.

22 Craig P., De Burca G. EU Law: Text, Cases and Materials, $6^{\text {th }}$ edition, Oxford University Press, 2015, p. 311.

23 Trstenjak V. National Sovereignity and the Principle of Primacy in EU Law and Their Importance for the Member States. Beijing Law Review, Vol. 4, Nr. 2, 2013, p. 72.

24 Tiesas 1964. gada 15. jūlija spriedums lietā C-6/64 Costa/E.N.E.L., 594. lpp. 
Konstitūciju Eiropai ${ }^{25}$, nosakot, ka "Konstitūcijai un ES iestāžu tiesību aktiem, ko tās pien,em savu kompetenču īstenošanai, ir augstāks spēks nekā dalībvalstu tiesību aktiem”"26, tomēr minētais līgums nestājās spēkā un tika aizstāts ar Lisabonas līgumu27, neiekḷaujot šajā līgumā attiecīgo pamatprincipu. Vienīgi Deklarācijā, ${ }^{28}$ kura pretēji ES pamatlīgumu protokoliem nav saistoša un ir ietverta Lisabonas līguma pielikumā, norādīts uz minēto ES pamatprincipu.

No Deklarācijas izriet, ka saskaņā ar iedibināto EST “judikatūru, Līgumiem un tiesību aktiem, ko ES ir pieņēmusi, pamatojoties uz Līgumiem, ir augstāks spēks nekā dalibvalstu tiesību aktiem, ievērojot nosacījumus, kuri noteikti ar attiecīgo judikatūru"29. Deklarācijā iekḷauta arī atsauce uz Padomes Juridiskā dienesta 2007. gada 22. jūnija atzinumu, atbilstoši kuram, lai arī Lisabonas līgumā nav ietverts pārākuma princips, šis apstāklis negroza minētā principa esamību un EST pastāvošo judikatūru. ${ }^{30}$

Papildus šajā sakarā būtiski piebilst, ka Deklarācijā nekas nav minēts par ES tiesību pārākumu pār dalībvalstu konstitūcijām, tomēr, ņemot vērā vispārējo formulējumu, kas ietverts Deklarācijā, kā arī EST judikatūru, ${ }^{31}$ tiek prezumēts, ka ES tiesības ir pārākas arī par dalībvalstu konstitūcijām. ${ }^{32}$ Lai gan minētā prezumpcija radusies, lai nodrošinātu ES tiesību vienveidīgu interpretāciju visās dalībvalstīs, sekmējot to saskanīgu un pilnīgu iedarbību, kā arī autonomiju, tomēr dalībvalstīm ir citāds viedoklis minētajā jautājumā - to apliecina, piemēram, tas, ka Līgums par Konstitūciju Eiropai, kurā nepārprotami bija iekḷauts ES pārākuma princips, nestājās spēkā.

\section{Pārākuma principa robežas - dalībvalstu redzējums}

Latvijā, pirms Satversmes tiesa norādīja tās vērtības, kuras nedrīkst tikt ierobežotas, iekḷaujoties ES, ${ }^{33}$ tādējādi nosakot integrācijas ES robežas, ${ }^{34}$ Saeima 2005. gada

25 Līgums par Konstitūciju Eiropai, OV C310, 16.12.2004, 1.-474. lpp.

26 Likuma "Par Līgumu par Konstitūciju Eiropai" 6. pants.

27 Lisabonas Līgums, ar ko groza Līgumu par Eiropas Savienību un Eiropas Kopienas dibināšanas līgumu, parakstīts Lisabonā 2007. gada 13. decembrī, OV C 306, 17.12.2007., 1./271. lpp.

28 Līguma par Eiropas Savienības darbïbu konsolidētā versija - Deklarācijas, kas pievienotas Lisabonas Līgumu, kas parakstīts 2007. gada 13. decembrī, pieņēmušās Starpvaldību - A. DEKLARĀCIJAS PAR LİGUMU NOTEIKUMIEM - 17. Deklarācija par Savienības tiesību aktu augstāku spēku, OV C 115, 9.5.2008., 344./344. lpp.

29 Ibid.

30 Ibid.

31 Piemēram, EST 2013. gada 26. februāra spriedums lietā C-399/11 Melloni, 59. punkts; EST 1978. gada 9. marta spriedums lietā C-106/77 Amministrazione delle finanze dello Stato/Simmenthal, 21. punkts.

32 EST 2010. gada 8. septembra spriedums lietā C-409/06 Winner Wetten, 61. punkts; EST 1970. gada 17. decembra spriedums lietā C-11/70 Internationale Handelsgesellschaft mbH/Einfuhr-und Vorratsstelle für Getreide und Futtermittel.

33 Plepa D. Satversmes tiesa kā konstitucionālo vērtību aizsardzības mehānisms, Konstitucionālās vērtības mūsdienu tiesiskajā telpā, I: Latvijas Universitātes Juridiskās fakultātes 6. starptautiskās zinātniskās konferences rakstu krājums. Rìga: LU Akadēmiskais apgāds, 2016, 85. lpp.

34 Osipova S. Latvijas Republikas konstitucionālā identitāte Satversmes tiesas spriedumos. Jurista Vārds, 03.07.2018., Nr. 27 (1033), 8.-13. lpp. 
2. jūnijā pieṇēma likumu "Par Līgumu par Konstitūciju Eiropai”35, ar kuru tika apstiprināts 2004. gada 29. oktobrī Romā parakstītais Līgums par Konstitūciju Eiropai un tā Nobeiguma akts ar deklarācijām. ${ }^{36}$ Ar šo rīcību Latvija faktiski atzina neierobežotu ES pārākuma principu, kurš izrietēja no minētā līguma un kurā nepārprotami bija noteikts, ka "ES iestāžu tiesību aktiem, ko tās pieņem savu kompetenču îstenošanai, ir augstāks spēks nekā dalībvalstu tiesību aktiem" ${ }^{\text {37 }}$.

Tomēr, n,emot vērā, ka 2005. gada 29. maijā Francijas un 2005. gada 1. jūnijā Nīderlandes pilsoņi tautas nobalsošanā noraidīja Līgumu par Konstitūciju Eiropai ${ }^{38}$ un ES dalībvalstis vienojās par jaunu līgumu grozījumu izstrādi, t. i., Lisabonas līgumu, ${ }^{39}$ Saeima 2008. gada 3. aprīlī pieñēma likumu "Par likuma "Par Lìgumu par Konstitūciju Eiropai” atzī̌sanu par spēku zaudējušu”. ${ }^{40}$ Šeit gan jānorāda, ka ne likuma "Par Līgumu par Konstitūciju Eiropai”"11, ne likuma "Par likuma "Par Līgumu par Konstitūciju Eiropai” atzī̌̌anu par spēku zaudējušu" ${ }^{42}$ atbilstîba Satversmei nav tikusi apstrīdēta. ${ }^{43}$ Tātad Satversmes tiesa nav pārbaudijjusi attiecīgo likumu atbilstību Satversmei, kā tas darīts Lisabonas līguma gadījumā, n,emot vērā, ka 2008. gada 8. maijā tika pieņemts likums "Par Lisabonas līgumu, ar ko groza Lìgumu par Eiropas Savienību un Eiropas Kopienas dibināšanas līgumu”, kas stājās spēkā 2008. gada 29. maijā. ${ }^{44}$

Tā radusies situācija, kur, no vienas puses, Latvijai kā dalībvalstij ir saistošs no EST judikatūras izrietošais ES pamatprincips, bet, no otras puses, Satversmes tiesa ir noteikusi pamatprincipus ${ }^{45}$, kurus ES tiesības nedrīkst aizskart. Līdz ar to Satversmei un no tās izrietošiem pamatprincipiem faktiski tiek pieškirts augstāks spēks nekā ES tiesībām. Uz minēto netieši norāda, piemēram, viens no Satversmes tiesas spriedumiem,

35 Likums "Par Līgumu par Konstitūciju Eiropai”. Latvijas Vēstnesis, 97 (3255), 21.06.2005.

36 Satversmes tiesas 2009. gada 7. aprīla spriedums lietā Nr. 2008-35-01, "Par likuma "Par Lisabonas līgumu, ar ko groza Līgumu par Eiropas Savienību un Eiropas Kopienas dibināšanas līgumu” atbilstību Latvijas Republikas Satversmes 101. pantam”,10.2. punkts.

37 Likuma "Par Līgumu par Konstitūciju Eiropai” 6. pants. Latvijas Vēstnesis, 97 (3255), 21.06.2005.

38 Whitlock Cr. France Rejects European Constitution. Washington Post Foreign Service 2005. gada 30. maijs. Pieejams: http://www.washingtonpost.com/wp-dyn/content/article/2005/05/29/ AR2005052900644.html??noredirect=on (aplūkots 11.05.2019.); Sciolino E. French Voters Soundly Reject European Union Constitution. The New York Times. 2005. gada 30. maijs. Pieejams: https:// www.nytimes.com/2005/05/30/world/europe/french-voters-soundly-reject-european-union-constitution.html [aplūkots 11.05.2019.].

39 Likuma "Par likuma "Par Līgumu par Konstitūciju Eiropai” atzī̌̌anu par spēku zaudējušu” anotācija. Pieejams: http://titania.saeima.lv/LIVS/SaeimaLIVS.nsf/0/367449605F4DFA1DC2257401002B 5DAA?OpenDocument [aplūkots 11.05.2019.].

40 Satversmes tiesas 2009. gada 7. aprīḷa spriedums lietā Nr. 2008-35-01, "Par likuma "Par Lisabonas līgumu, ar ko groza Līgumu par Eiropas Savienỉbu un Eiropas Kopienas dibināšanas līgumu” atbilstỉbu Latvijas Republikas Satversmes 101. pantam”, 10.2. punkts.

41 Likums “Par Līgumu par Konstitūciju Eiropai”. Latvijas Vēstnesis, 21.06.2005., 97 (3255).

42 Par likuma "Par Līgumu par Konstitūciju Eiropai” atzīšanu par spēku zaudējušu. Latvijas Vēstnesis, 18.04.2008., 61 (3845).

43 Satversmes tiesas 2009. gada 7. aprīla spriedums lietā Nr. 2008-35-01, "Par likuma "Par Lisabonas līgumu, ar ko groza Līgumu par Eiropas Savienību un Eiropas Kopienas dibināšanas līgumu” atbilstību Latvijas Republikas Satversmes 101. pantam”, 10.2. punkts.

44 Likums "Par Lisabonas līgumu, ar ko groza Līgumu par Eiropas Savienību un Eiropas Kopienas dibināšanas līgumu”. Latvijas Vēstnesis, 82 (3866), 28.05.2008.

45 Satversmes tiesas 2009. gada 7. aprīla spriedums lietā Nr. 2008-35-01 [..], 17. punkts. 
kurā pēc tam, kad no EST tika saņemta atbilde uz prejudiciāliem jautājumiem, Satversmes tiesa nonāca pie citāda secinājuma nekā EST savā nolēmumā. ${ }^{46}$ Turklāt līdzīgā situācijā ir arī citas dalībvalstis, piemēram, Vācijā, ${ }^{47}$ Čehijā, ${ }^{48}$ Bel,gijajā ${ }^{49}$ tiek atzīts, ka šo valstu konstitūcijas konkrētos jautājumos ir pārākas par ES tiesībām.

Tādējādi dalībvalstis atzīst ES tiesību pārākumu, tomēr līdz noteiktām robežām. ${ }^{50}$ Šajā sakarā jāuzsver, ka tas ir tikai dalībvalstu vienpusējs skatījums, kurš nav saskaṇots ar ES, ņemot vērā EST nostāju minētajā jautājumā. Piemēram, Melloni ${ }^{51}$ lietā EST vēlreiz atgādināja jau judikatūrāas nostiprināto atziņu, ka apstāklis, ka dalībvalsts atsaucas uz savām tiesībām, pat konstitucionāla rakstura normām, neietekmē ES tiesību iedarbību šìs valsts teritorijā.

\section{LES 4. panta otrā daḷa}

Saistībā ar iepriekš norādīto uzmanība vēršama uz LES 4. panta otro daḷu, kas ir viens no ES pārākuma principa ierobežojošiem instrumentiem, kurš izriet no ES pamatlīguma. Minētajā tiesību normā noteikts: "ES respektē dalībvalstu [..] nacionālo identitāti, kas raksturīga to politiskajām un konstitucionālajām pamatstruktūrām, tostarp regionālajām un vietējām pašvaldībām.[..]” Tomēr jāuzsver, ka ne ES, ne arī EST nav sniegusi nepārprotamu un izsmel̦ošu skaidrojumu, kā saprast šajā tiesību normā ietverto jēdzienu "nacionālā identitāte". Tāpat jāatzīmē, ka pastāv neizpratne, vai jēdziens "nacionālā identitāte" ir vai nav sinonīms jēdzienam "konstitucionālā identitāte”. Profesors Harijs Tumans norādījis, ka nacionālās identitātes izpratne atškiriras, piemēram, Francijas izpratne par nacionālo identitāti balstās uz politisko izcelsmi,

46 Satversmes tiesas 2018. gada 18. decembra spriedums lietā "Par Ministru kabineta 2015. gada 14. aprīla noteikumu Nr. 187 “Grozïjums Ministru kabineta 2004. gada 30. novembra noteikumos Nr. 1002 "Kārtība, kādā ieviešams programmdokuments "Latvijas Lauku attīstības plāns Lauku attīstības programmas īstenošanai 2004.-2006. gadam””” atbilstību Latvijas Republikas Satversmes 105. pantam".

47 Vācijas konstitucionālās tiesas 2009. gada 30. jūnija spriedums lietā 2 BvE 2/08. Pieejams: http:// www.bundesverfassungsgericht.de/SharedDocs/Entscheidungen/EN/2009/06/es20090630_2bve000208en.html (aplūkots 11.05.2019.)

48 Čehijas konstitucionālās tiesas 2008. gada 26. novembra spriedums lietā 2008/11/26 - Pl. ÚS 19/08: Treaty of Lisbon I. Pieejams: https://www.usoud.cz/en/decisions/20081126-pl-us-1908-treaty-oflisbon-i-1/ [aplūkots 11.05.2019.].

49 Gérard P., Verrijdt W. Belgian Constitutional Court Adopts National Identity Discourse. European Constitutional Law Review, 2017, pp. 182-205. Pieejams: http://constituante.be/wp-content/ uploads/2017/03/Gerard_Verrijdt_Belgian-Constitutional-Court-Adopts-National-Identity-Discourse.pdf [aplūkots 11.05.2019.].

50 Besselink L. F. M. National and constitutional identity before and after Lisbon. Utrecht Law Review, 6(3), 2010, pp. 44-49. Pieejams: https://www.utrechtlawreview.org/articles/abstract/10.18352/ ulr.139/ [aplükots 11.05.2019.].

51 EST 2013. gada 26. februāra sprieduma spriedums lietā C-399/11 Melloni, 59. punkts.

52 Piemēram, EST 2010. gada 8. septembra spriedums lietā C-409/06 Winner Wetten, 61. punkts. 
turpretim Vācijā prevalē tieši etniskā izcelsme. ${ }^{53}$ Turklāt Vācijā tiek lietots jēdziens "konstitucionālā identitāte", nevis "nacionālā identitāte".

\subsection{Nacionālā identitāte}

Nacionālās identitātes jēdziena tvērums neapšaubāmi ir izteikti plašs, ņemot vērā nācijas kā idejas attīstību vēsturiskā skatījumā ${ }^{-54}$. Tomēr, aplūkojot nacionālās identitātes jēdzienu no sociologijas viedokḷa, redzams, ka ar šo jēdzienu saprot indivīda piederības izjūtu valstij. ${ }^{55}$ Turklāt minētajam jēdzienam pastāv vairākas dimensijas, t. i., psihologiskā dimensija, kultūra, teritoriālā piederība, vēsturiskās atmiṇas, kā arī politiskā dimensija. ${ }^{56}$ Tāpat šo jēdzienu nedrīkst jaukt ar etnisko identitāti. Lai gan abi norādītie jēdzieni nav viens otru izslēdzoši, bet drīzāk papildinoši, jāatceras, ka ar etnisko identitāti jāsaprot piederība etniskajai grupai, kuras pamatā ir kopēja kultūra un valoda ${ }^{57}$ Piemēram, "latviešu etniskā identitāte norāda uz piederību latviešu kultūras kopienai, bet nacionālā identitāte - uz valstisko piederību" 58 , tādējādi etniskā identitāte faktiski veido nacionālās identitātes kodolu. ${ }^{59}$

Savukārt attiecībā uz nacionālās identitātes jēdzienu ES pamatlīgumos norādāms, ka šis jēdziens bija ietverts jau Māstrihtas līguma F pantā, no kura nepārprotami izrietēja, ka "ES respektē dalībvalstu nacionālo identitāti" ${ }^{\circ 0}$. Tomēr minētais ES pienākums ar Lisabonas līgumu tika pārformulēts, un tagad LES 4. panta otrajā daļā noteikts: "ES respektē dalībvalstu nacionālo identitāti, kas raksturīga to politiskajām un konstitucionālajām pamatstruktūrām, tostarp reǵionālajām un vietējām pašvaldībām.” Šì norma garantē - lai arī ES ir pārnacionāla, tomēr dalībvalstis, to konstitucionālās pamatstruktūras, vērtības, principi un pamattiesības turpina pastāvēt, lai gan dalībvalsts kḷuvusi par ES daļu. ${ }^{61}$ Vienlaikus norādāms, ka ar Lisabonas līgumu minētais jēdziens sašaurināts.

Tas tā ir, jo pēc Lisabonas līguma nacionālās identitātes respektēšana izpaužas tādā veidā, ka LES 4. panta otrā daḷa cita starpā aizsargā kompetenču sadalījumu dalībvalstīi, ${ }^{62}$ piemēram, ES nevar apstrīdēt pilnvaru sadali dalībvalsts teritoriālajām pašvaldībām. ${ }^{63}$ Tāpat ar LES 4. panta otro dalu noteiktā aizsardzība attiecas, piemēram,

53 2018. gada 29. novembra intervija ar profesoru Hariju Tumanu. Viktorijas Soṇecas personiskā arhīva materiāli.

54 Андерсон Б. Воображаемые сообщества. Размышиения об истоках и распространении национамизма. Москва: Канон-пресс-Ц, 2001.

55 Latvija: pārskats par tautas attīstību. 2010/2011: Nacionālā identitāte, mobilitāte un rīcībspēja. B. Zepa un E. Kḷave (galv. red.). Rìga: LU Sociālo un politisko pētījumu institūts, 2011, 15. lpp.

56 Ibid., 11.lpp.

57 Ibid.

58 Ibid., 12. lpp.

59 Ibid.

60 Māstrihtas līgums. Pieejams: https://europa.eu/european-union/sites/europaeu/files/docs/body/ treaty_on_european_union_en.pdf.[aplūkots 11.05.2019.].

61 Satversmes tiesas 2009. gada 7. aprīḷa spriedums lietā Nr. 2008-35-01 "Par likuma "Par Lisabonas līgumu, ar ko groza Līgumu par Eiropas Savienību un Eiropas Kopienas dibināšanas līgumu” atbilstību Latvijas Republikas Satversmes 101. pantam”[..], 16.3. punkts.

62 EST 2016. gada 21. decembra spriedums lietā C-51/15 Remondis, 40. punkts.

63 EST 2014. gada 12. jūnija spriedums lietā C-156/13 Digibet un Albers, 34. punkts. 
uz pilnvaru reorganizāciju dalībvalstī. ${ }^{64}$ Tomēr no EST judikatūras neizriet nacionālās identitātes kā atsevišķa jēdziena aizsardzība pret ES iejaukšanos, jo EST minēto tiesību normu piemēro, izmantojot tikai gramatisko interpretācijas metodi, nesniedzot nacionālās identitātes jēdziena tvērumu un tā izpratni no ES puses.

\subsection{Konstitucionālā identitāte}

Lai gan jēdziens "konstitucionālā identitāte”, piemēram, Vācijā ir pazīstams kopš 1919. gada, ${ }^{65}$ Latvijā tas ieviests kopš 2012. gada, ${ }^{66}$ ar šo jēdzienu saprotot valstī pastāvošās konstitucionālās vērtības, kas ir konkrētas sabiedrības pamatvērtības, kuras nosaka valsts identitāti. ${ }^{67}$

Pamatavots jēdzienam “konstitucionālā identitāte” meklējams Valsts prezidenta izveidotās Konstitucionālo tiesību komisijas 2012. gada 17. septembra atzinumā "Par Latvijas valsts konstitucionāliem pamatiem un neaizskaramo kodolu" ${ }^{68}$, tomēr norādāms, ka šajā atzinumā nav analizēts jēdziens "nacionālā identitāte". Kā vienu no piemēriem saistībā ar Latvijas konstitucionālo identitāti var minēt valsts nepārtrauktības principu, kas ir viens no Latvijas svarīgākajiem vispārējiem tiesību principiem. Minētais princips izriet no pamatnormas apstākḷ,os, kad Latvijas tauta varēja atgūt savas valsts neatkarību pēc ilgas, prettiesiskas okupācijas. ${ }^{69} \mathrm{Li} d z$ ar to, lai gan nenoliedzami konstitūcijās ir iekodētas norādes uz valsts vēsturi, tradīcijām, valodu, valsts dibināšanas apstākḷiem un valstiskuma attīstību, valsts mērḳiem ${ }^{70}$, tomēr būtiski izprast atškłirību starp iepriekš nacionālās identitātes un konstitucionālās identitātes jēdzieniem, lai noteiktu saskares punktus, kurus atzīst ES. ${ }^{71}$

Velkot paralēles ar nacionālo identitāti, par dalībvalstu konstitucionālo identitāti ir izteikts viedoklis - ja "respekts" pret dalíbvalstu konstitucionālo identitāti var radìt legitīimu interesi, kas principā varētu pamatot atkāpi no saistībām, ko uzliek ES tiesības, dalībvalsts uz to var atsaukties, lai pamatotu tās konstitucionālo tiesību normu izvērtējumu, kas papildina ES tiesību normas, lai nodrošinātu tās teritorijā tādu principu un noteikumu ievērošanu, kas paredzēti šajās normās vai ir to pamatā. Tomēr respekts

64 EST 2016. gada 21. decembra spriedums lietā C-51/15 Remondis, 41. punkts.

65 Polzin M. Constitutional identity, unconstitutional amendments and the idea of constituent power: The development of the doctrine of constitutional identity in German constitutional law, International Journal of Constitutional Law, Volume 14, Issue 2, 2016, 411.-421. lpp. Pieejams: https://datubazes. lanet.lv:4876/10.1093/icon/mow035 [aplūkots 11.05.2019.].

66 Osipova S. Latvijas Republikas konstitucionālā identitāte Satversmes tiesas spriedumos. Jurista Vārds, 03.07.2018., Nr. 27 (1033), 8.-13. lpp.

67 Ibid.

68 Valsts prezidenta izveidotās Konstitucionālo tiesību komisijas 2012. gada 17. septembra atzinums "Par Latvijas valsts konstitucionāliem pamatiem un neaizskaramo kodolu”. Pieejams: http://blogi.lu.lv/ tzpi/files/2017/03/17092012_Viedoklis_2.pdf [aplūkots 11.05.2019.].

69 Ziemele I. Satversmes tiesas loma konstitucionālo principu aizsardzībā un piemērošanā. Jurista Vārds, 21.11.2017., Nr. 48 (1002), 20.-24. lpp.

70 Pleps J. Baltijas valstu konstitucionālā identitāte. Jurista Vārds, 23.08.2016., Nr. 34 (937), 10.-13. lpp.

71 Besselink L. F. M. National and constitutional identity before and after Lisbon. Utrecht Law Review, 6(3), 2010, 44.-49. lpp. Pieejams: https://www.utrechtlawreview.org/articles/abstract/10.18352/ ulr.139/ [aplūkots 11.05.2019.]. 
pret dalībvalstu konstitucionālo identitāti nevar tikt uztverts kā absolūta piekāpšanās jebkuras dalībvalsts konstitucionālas normas priekšā, jo tādā gadijjumā dalībvalstis varētu izmantot to konstitūcijas kā līdzekli, lai atbrīvotos no pienākumiem, ko noteiktās jomās uzliek ES tiesỉbas. ${ }^{72}$ Līdz ar to pastāv konkrēts kopums, kur pārklājas abas minētās identitātes, un tieši šo kopumu atzīst ES - kopējais saskares punkts.

\section{Kopsavilkums}

1. Pārākuma princips, kurš neizriet no ES pamatlīgumiem, bet iedibināts ar EST judikatūru, nav absolūts. Šo principu var ierobežot ne tikai LES 4. panta otrā daļa, bet arī ES un dalïbvalstu vienota izpratne par normatīvo aktu hierarhiju konkrētos gadỉjumos, ņemot vērā, ka minētã izpratne konkretizē LES 4. panta otrajā dạ̦ā ietverto jēdzienu "nacionālā identitāte".

2. Dalībvalstīm un ES ir daudzas kopīgas vērtības, tomēr pastāv arī atšķirīibas to izpratnē, un, kamēr EST un dalïbvalstu izpratne par vērtībām neatšķiras, nepastāv arī domstarpỉbas, tomēr brīdī, kad šì izpratne atškiras, veidojas kolīzija, n’emot vērā, ka dalībvalstis nav gatavas upurēt no to konstitūcijām izrietošo izpratni par konkrētām vērtībām.

3. Tiek prezumēts, ka ES tiesības ir pārākas par dalïbvalstu konstitūcijām. Minētā prezumpcija radusies, lai nodrošinātu ES tiesību vienveidīgu interpretāciju visās dalībvalstīs, sekmējot to saskanīgu un pilnīgu iedarbỉbu, kā arī autonomiju, tomēr dalībvalstīm ir citāds viedoklis minētajā jautājumā - to apliecina, piemēram, tas, ka nestājās spēkā Līgums par Konstitūciju Eiropai, kurā nepārprotami bija iekḷauts ES pārākuma princips.

4. No vienas puses, Latvijai kā dalībvalstij ir saistošs no EST judikatūras izrietošais ES pāaākuma princips, bet, no otras puses, Satversmes tiesa ir noteikusi pamatprincipus, kurus ES tiesības nedrīkst aizskart, tādējādi faktiski piešķirot Satversmei un no tās izrietošiem pamatprincipiem augstāku spēku nekā ES tiesībām.

5. Ar Lisabonas līgumu LES 4. pantā iekḷautais jēdziens "nacionālā identitāte" ir sašaurināts. Turklāt no EST judikatūras neizriet nacionālās identitātes kā atsevišķa jēdziena aizsardzība pret ES iejaukšanos, jo EST minēto tiesību normu piemēro, izmantojot tikai gramatisko interpretācijas metodi, nesniedzot nacionālās identitātes jēdziena tvērumu un tā izpratni no ES puses.

\section{BIBLIOGRĀFIJA}

\section{Literatūra}

1. Besselink L. F. M. National and constitutional identity before and after Lisbon. Utrecht Law Review, 6(3), 2010. Pieejams: https://www.utrechtlawreview.org/articles/abstract/10.18352/ ulr.139/ [aplūkots 11.05.2019.].

72 Generāladvokāta Migela Pojareša Maduru (Miguel Poiares Maduro) 2008. gada 8. oktobra secinājumi lietā C-213/07, ECLI:EU:C:2008:544, 33. punkts. 
2. Carulla Santiago R. EU Law before the Spanish Constitutional Court. Review by the constitutional courts of proceedings before ordinary courts applying Community law. Strasbourg CCS 2006/05. Pieejams: http://www.venice.coe.int/webforms/documents/default.aspx? pdffile $=$ CDL-JU(2006)025-e [aplūkots 11.05.2019.].

3. Claes M. The Validity and Primacy of EU Law and the "Cooperative Relationship" between National Constitutional Courts and the Court of Justice of the European Union. Maastricht Journal of European and Comparative Law, 2016, pp. 151-170.

4. Craig P., De Burca G. EU Law: Text, Cases and Materials, $6^{\text {th }}$ edition. Oxford University Press, 2015.

5. Ferraro F., Carmona J. Les droits fondamentaux dans l'Union européenne. Le rôle de la Charte après le Traité de Lisbonne. Service de recherche du Parlement européen. 2015. Pieejams: http://www.europarl.europa.eu/RegData/etudes/IDAN/2015/554168/EPRS_IDA\%28 2015\%29554168_FR.pdf [aplūkots 11.05.2019.].

6. Geiger R. EU Constitutionalism and the German Basic Law. The Jean Monnet / Robert Schuman Paper Series, Vol. 5, No. 1A, January 2005. Pieejams: http://aei.pitt.edu/8135/1/geigerfinal.pdf [aplūkots 11.05.2019.].

7. Gérard P., Verrijdt W. Belgian Constitutional Court Adopts National Identity Discourse. European Constitutional Law Review, 2017. Pieejams:http://constituante.be/wp-content/ uploads/2017/03/Gerard_Verrijdt_Belgian-Constitutional-Court-Adopts-National-IdentityDiscourse.pdf [aplūkots 11.05.2019.].

8. Latvija: pārskats par tautas attīstību. 2010/2011: Nacionālā identitāte, mobilitāte un rīcībspēja. B. Zepa un E. Kḷave (galv. red.). Rīga: LU Sociālo un politisko pētījumu institūts, 2011.

9. Lenaerts K., Corthaut T. Of birds and hedges: the role of primacy in invoking norms of EU law. European Law Review, Vol. 31, Issue 3, 2006, pp. 287-315.

10. Levits E. Eiropas Savienība kā vērtību savienība. Jurista Vārds, 08.05.2018., Nr. 19 (1025), 39.-49. lpp.

11. Levits E. Satversme un Eiropas Savienība. Jurista Vārds, 8.06.2000., Nr. 23.

12. Osipova S. Latvijas Republikas konstitucionālā identitāte Satversmes tiesas spriedumos. Jurista Vārds, 03.07.2018., Nr. 27 (1033), 8.-13. lpp.

13. Plepa D. Satversmes tiesa kā konstitucionālo vērtību aizsardzības mehānisms, Konstitucionālās vērtības mūsdienu tiesiskajā telpā, I: Latvijas Universitātes Juridiskās fakultātes 6. starptautiskās zinātniskās konferences rakstu krājums. Rīga: LU Akadēmiskais apgāds, 2016, 83.-97. lpp.

14. Pleps J. Baltijas valstu konstitucionālā identitāte. Jurista Vārds, 23.08.2016., Nr. 34 (937), 10.-13. lpp.

15. Polzin M. Constitutional identity, unconstitutional amendments and the idea of constituent power: The development of the doctrine of constitutional identity in German constitutional law. In: International Journal of Constitutional Law, Volume 14, Issue 2, 2016. Pieejams: https:// datubazes.lanet.lv:4876/10.1093/icon/mow035 [skatits 10.01.2019.].

16. Sciolino E. French Voters Soundly Reject European Union Constitution. The New York Times. 2005.0530.

17. Soṇeca V. Brexit stāsts: to be continued vai tomēr the end. Jurista Vārds, 08.01.2019., Nr. 1 (1059), 21.-25. lpp.

18. Stein T. Always Steering a Straight Course? The German Federal Constitutional Court and European Integration. ERA Forum, 2011. Pieejams: https://link.springer.com/content/pdf/ 10.1007/s12027-011-0200-5.pdf (aplūkots 11.05.2019.). 
19. Trstenjak V. National Sovereignity and the Principle of Primacy in EU Law and Their Importance for the Member States. Beijing Law Review, 2013. Vol. 4, Nr. 2., pp. 71-76.

20. Valsts prezidenta izveidotās Konstitucionālo tiesību komisijas 2012. gada 17. septembra atzinums "Par Latvijas valsts konstitucionāliem pamatiem un neaizskaramo kodolu". Pieejams: http://blogi.lu.lv/tzpi/files/2017/03/17092012_Viedoklis_2.pdf (aplūkots 11.05.2019.).

21. Vataman D. The relationship between European Union law and Romanian law in the context of the law. Challenges of the Knowledge Society. Pieejams: http://cks.univnt.ro/uploads/ cks_2015_articles/index.php?dir=03_public_law\%2F\&download=CKS+2015_public_law_ art.079.pdf [aplūkots 11.05.2019.].

22. Whitlock Cr. France Rejects European Constitution. Washington Post Foreign Service 2005. 05.30. Pieejams: http://www.washingtonpost.com/wp-dyn/content/article/2005/05/29/ AR2005052900644.html??noredirect=on [aplūkots 11.05.2019.]. Pieejams: https://www. nytimes.com/2005/05/30/world/europe/french-voters-soundly-reject-european-union-constitution.html [aplūkots 11.05.2019.].

23. Ziemele I. Satversmes tiesas loma konstitucionālo principu aizsardzībā un piemērošanā. Jurista Vārds, 21.11.2017., Nr. 48 (1002), 20.-24. lpp.

24. Андерсон Б. Воображаемые сообщества. Размышиения об истоках и распространении национализма. М., 2001.

\section{Dokumentārie avoti}

25. 2018. gada 29. novembra intervija ar profesoru Hariju Tumanu. Viktorijas Soṇecas personiskā arhīva materiāli.

\section{Normativie akti}

26. Līgums par Eiropas Savienību, OV C 115, 9.5.2008.

27. Līguma par Eiropas Savienības darbïbu konsolidētā versija, OV C 326, 26.10.2012., 47./390. lpp.

28. Lisabonas Līgums, ar ko groza Līgumu par Eiropas Savienību un Eiropas Kopienas dibināšanas lìgumu, parakstīts Lisabonā 2007. gada 13. decembrī, OV C 306, 17.12.2007., 1./271. lpp.

29. Līguma par Eiropas Savienības darbību konsolidētā versija - Deklarācijas, kas pievienotas Lisabonas Līgumu, kas parakstīts 2007. gada 13. decembrī, pieņēmušās Starpvaldỉbu - A. DEKLARĀCIJAS PAR LİGUMU NOTEIKUMIEM - 17. Deklarācija par Savienības tiesību aktu augstāku spēku, OV C 115, 9.5.2008., 344./344. lpp.

30. Māstrihtas līgums. Pieejams: https://europa.eu/european-union/sites/europaeu/files/docs/ body/treaty_on_european_union_en.pdf [aplūkots 11.05.2019.].

31. Eiropas Savienības Pamattiesību harta, OJ V 326, 26.10.2012, 391./407. lpp.

32. Vācijas Konstitūcija. Pieejams: https://www.btg-bestellservice.de/pdf/80201000.pdf.[aplūkots 11.05.2019.].

33. Beḷgijas Konstitūcija. Pieejams: https://www.dekamer.be/kvvcr/pdf_sections/publications/ constitution/GrondwetUK.pdf [aplūkots 11.05.2019.].

34. Likums "Par Līgumu par Konstitūciju Eiropai”. Latvijas Vēstnesis, 97 (3255), 21.06.2005.

35. Likums "Par Lisabonas līgumu, ar ko groza Līgumu par Eiropas Savienību un Eiropas Kopienas dibināšanas līgumu””. Latvijas Vēstnesis, 82 (3866), 28.05.2008. Pieejams: https://likumi.lv/ ta/id/175929-par-lisabonas-ligumu-ar-ko-groza-ligumu-par-eiropas-savienibu-un-eiropas-kopienas-dibinasanas-ligumu [aplūkots 11.05.2019.]. 
36. Par likuma "Par Līgumu par Konstitūciju Eiropai” atzī̌̌anu par spēku zaudējušu. Latvijas Vēstnesis, 61 (3845), 18.04.2008. https://likumi.lv/ta/id/174125-par-likuma-par-ligumu-parkonstituciju-eiropai-atzisanu-par-speku-zaudejusu [aplūkots 11.05.2019.].

37. Likuma "Par likuma "Par Līgumu par Konstitūciju Eiropai” atzīšanu par spēku zaudējušu” anotācija. Pieejams: http://titania.saeima.lv/LIVS/SaeimaLIVS.nsf/0/367449605F4DFA1DC22 57401002B5DAA? OpenDocument aplūkots [aplūkots 11.05.2019.].

38. Likums "Par Lisabonas lïgumu, ar ko groza Lìgumu par Eiropas Savienību un Eiropas Kopienas dibināšanas līgumu”. Latvijas Vēstnesis, 82 (3866), 28.05.2008. Pieejams https://likumi.lv/ ta/id/175929-par-lisabonas-ligumu-ar-ko-groza-ligumu-par-eiropas-savienibu-un-eiropas-kopienas-dibinasanas-ligumu [aplūkots 11.05.2019.].

\section{Judikatūra}

39. EST 1964. gada 15. jūlija spriedums lietā C-6/64 Costa/E.N.E.L.

40. EST 1970. gada 17. decembra spriedums lietā C-11/70 Internationale Handelsgesellschaft mbH/ Einfuhr- und Vorratsstelle für Getreide und Futtermittel.

41. EST 1978. gada 9. marta spriedums lietā C-106/77 Amministrazione delle finanze dello Stato/ Simmenthal, ECLI:EU:C:1978:49.

42. Ģ̣enerāladvokāta Migela Pojareša Maduru (Miguel Poiares Maduro) 2008. gada 8. oktobra secinājumi lietā C-213/07.

43. EST 2010. gada 8. septembra spriedums lietā C-409/06 Winner Wetten.

44. EST 2013. gada 26. februāra spriedums lietā C-399/11 Melloni.

45. EST 2014. gada 12. jūnija spriedums lietā C-156/13 Digibet un Albers.

46. EST 2014. gada 18. decembra atzinums Avis 2/13 Adhésion de l'Union à la CEDH.

47. EST 2016. gada 21. decembra spriedums lietā C-51/15 Remondis.

48. EST 2018. gada 5. jūnija spriedums lietā C-673/16 Coman u. c.

49. EST 2018. gada 10. decembra spriedums lietā C-621/18 Wightman u. c.

50. Satversmes tiesas 2008. gada 17. janvāra sprieduma lietā Nr. 2007-11-03, "Par Rīgas teritorijas plānojuma daļas 2006.-2018. gadam, kas attiecas uz Rìgas brīvostas teritoriju, atbilstību Latvijas Republikas Satversmes 115. pantam”.

51. Satversmes tiesas 2009. gada 7. aprīla spriedums lietā Nr. 2008-35-01, "Par likuma "Par Lisabonas līgumu, ar ko groza Līgumu par Eiropas Savienību un Eiropas Kopienas dibināšanas līgumu" atbilstïbu Latvijas Republikas Satversmes 101. pantam".

52. Satversmes tiesas 2018. gada 29. jūnija spriedums lietā Nr. 2017-28-0306, „Par Rīgas domes 2015. gada 9. jūnija saistošo noteikumu Nr. 148 "Par nekustamā īpašuma nodokli Rīgā" 3. ${ }^{1}$ punkta atbilstību Latvijas Republikas Satversmes 91. pantam un Liguma par Eiropas Savienïbas darbïbu 18. panta pirmajai daļai un 21. panta pirmajai daļai”.

53. Satversmes tiesas 2018. gada 18. decembra spriedums lietā "Par Ministru kabineta 2015. gada 14. aprịla noteikumu Nr. 187 “Grozijums Ministru kabineta 2004. gada 30. novembra noteikumos Nr. 1002 "Kārtība, kādā ieviešams programmdokuments "Latvijas Lauku attīstības plāns Lauku attīstības programmas īstenošanai 2004.-2006. gadam"”'”” atbilstîbu Latvijas Republikas Satversmes 105. pantam".

54. Čehijas konstitucionālās tiesas 2008. gada 26. novembra spriedums lietā 2008/11/26-Pl. ÚS 19/08: Treaty of Lisbon I. Pieejams: https://www.usoud.cz/en/decisions/20081126-pl-us1908-treaty-of-lisbon-i-1/ [aplūkots 11.05.2019.]. 
55. Vācijas konstitucionālās tiesas 2009. gada 30. jūnija spriedums lietā 2 BvE 2/08. Pieejams: http://www.bundesverfassungsgericht.de/SharedDocs/Entscheidungen/EN/2009/06/es20090630_2bve000208en.html [aplūkots 11.05.2019.].

56. Beḷgijas konstitucionālās tiesas 2016. gada 28. aprīla spriedums lietā Nr. 62/2016. Pieejams: http://www.const-court.be/en/common/home.html (aplükots 11.05.2019.).

57. Vācijas konstitucionālās tiesas 2018. gada 6. jūlija spriedums lietā 2 BvR 2661/06, 53.-54. paragräfs. Pieejams: https://www.bundesverfassungsgericht.de/SharedDocs/Entscheidungen/EN/2010/07/rs20100706_2bvr266106en.html [aplūkots 11.05.2019.]. 